\title{
Experimental study of an aerospace titanium alloy under various thermal and tensile loading rate conditions
}

\author{
Brian T. Gockel ${ }^{1,2^{*}}$, Ryan S. Kolesar ${ }^{1}$ and Anthony D. Rollett ${ }^{2}$
}

\author{
* Correspondence: \\ brian.gockel.1@us.af.mil \\ ${ }^{1}$ U.S. Air Force Research Laboratory, \\ Wright-Patterson, $\mathrm{OH}$ 45433-7817, USA \\ 2Department of Materials Science \\ and Engineering, Carnegie Mellon \\ University, 5000 Forbes Ave, \\ Pittsburgh, PA 15213, USA
}

\begin{abstract}
Microstructure characterization and tensile testing was performed on flat samples machined from a 4.77-mm-thick sheet of Ti-6Al-2Sn-4Zr-2Mo-0.1Si at a range of temperatures $\left(23^{\circ} \mathrm{C}\right.$ up to $650^{\circ} \mathrm{C}$ ) and two strain rates $\left(8.33 \times 10^{-5} / \mathrm{s}\right.$ and $10^{-2} / \mathrm{s}$ ). A minimum of three repeats were conducted at each test condition. Each test recorded load, displacement, strain, time, and temperature for the duration of the test, and the complete raw data files are provided along with area measurements. The dataset demonstrates the changing strain rate and temperature sensitivity to the yield stress, work-hardening slope, and the ultimate stress. The completeness of this dataset and its possible applications are discussed. The complete data files that were collected along with specimen measurements and microstructural texture files are available at the National Institute of Standards and Technology (NIST) repository [1].
\end{abstract}

Keywords: Ti-6242S, Constitutive data, Stress-strain curve, Tensile dataset

\section{Data description}

\section{Introduction}

Testing and measuring the constitutive response of a material across a broad spectrum of conditions provides essential experimental data to designers and computational modelers on which they can base their calculations and make predictions of component performance. The availability of data is often limited by the cost and time required to characterize a material. Although standard tensile test data are available for many materials, the data often exist across multiple publications, laboratories, and batches of material and when presented do not always contain the detailed testing information required when modeling or designing. In particular, a coherent set of mechanical response data measured over a range of temperatures and strain rates on a single batch of material is far less common but is critical for applications in which those parameters vary during a loading cycle [2].

Material property data exist for Ti-6Al-2Sn-4Zr-2Mo-0.1Si (Ti-6242S) in journal articles and handbooks $[3,4]$ and technical reports $[5,6]$ and most certainly exists within company databases [7]. However, typically each dataset was generated for a specific set of conditions and does not cover a large enough design space or provide detailed setup and variability data required for detailed material models. 
Table 1 Chemical composition in weight percent of 4.77-mm-thick Ti-6242S sheet

\begin{tabular}{lllllllll}
\hline & $\mathrm{Al}$ & $\mathrm{Sn}$ & $\mathrm{Zr}$ & $\mathrm{Mo}$ & $\mathrm{Si}$ & $\mathrm{C}$ & $\mathrm{N}$ & $\mathrm{O}$ \\
\hline Measured & 5.96 & 1.98 & 3.92 & 1.99 & 0.09 & 0.02 & $<0.01$ & 0.10 \\
\hline
\end{tabular}

This article is aimed at providing a completely documented dataset of tensile test data and supporting microstructure information of a 4.77-mm-thick sheet of Ti-6242S tested at temperatures ranging from $23{ }^{\circ} \mathrm{C}$ to $650{ }^{\circ} \mathrm{C}$ and at nominal strain rates of quasi-static (QS) $\left(8.33 \times 10^{-5} / \mathrm{s}\right)$ and higher rate of (HS) $10^{-2} / \mathrm{s}$. This dataset supports and supplements the data provided in the Military Handbook [6] and the ASM Atlas of Stress-Strain Curves [4]. In particular, the experimental data aims to quantify the temperature and strain-rate sensitivity of the Ti-6242S alloy. By connecting the microstructure to the tensile performance, this article seeks to provide a complete dataset that can be used to develop constitutive models that can range from continuum to microstructurally based.

\section{Test methods}

\section{Material background and specimen design}

The titanium alloy Ti-6Al-2Sn-4Zr-2Mo-0.1Si, herein referred to as Ti-6242S, is an aerospace alloy that combines high strength, low weight, and high temperature resiliency [8]. Because of this combination of properties, Ti-6242S has been used for decades in gas turbine engines [9]. Such demanding environments result in high temperatures and tensile dynamic loading. Recently, Ti-6242S has been under investigation for high-temperature structural applications that include temperatures above $538{ }^{\circ} \mathrm{C}$ as well as dynamic loading on the order of $10^{-2} / \mathrm{s}$ [5-7].

The alloying elements primarily serve to stabilize the hexagonal alpha phase, with aluminum, tin, and zirconium all acting as alpha stabilizers. The molybdenum stabilizes the bcc beta phase, and the addition of silicon provides an increase in creep resistance [9]. The beta transus temperature is approximately $990{ }^{\circ} \mathrm{C}$, and the melting temperature is approximately $1705{ }^{\circ} \mathrm{C}$ [10]. Ti-6242S begins to creep

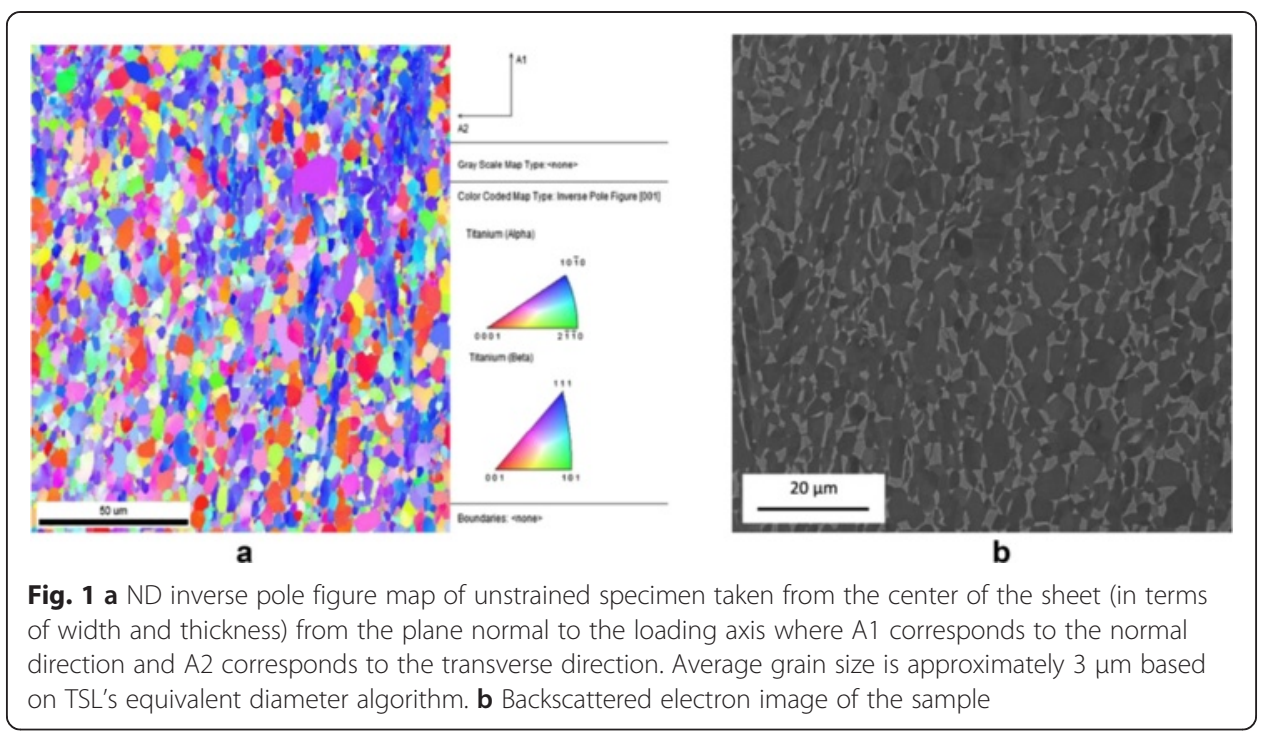




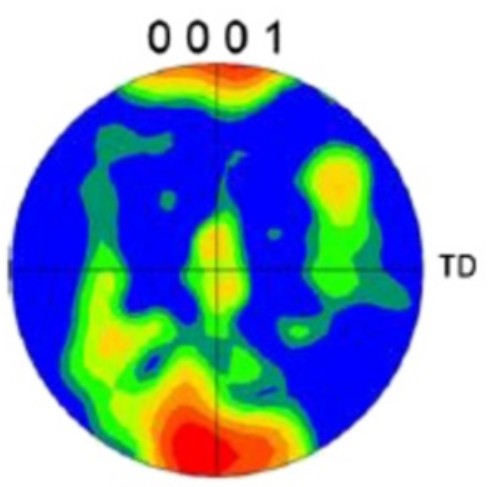

ND_

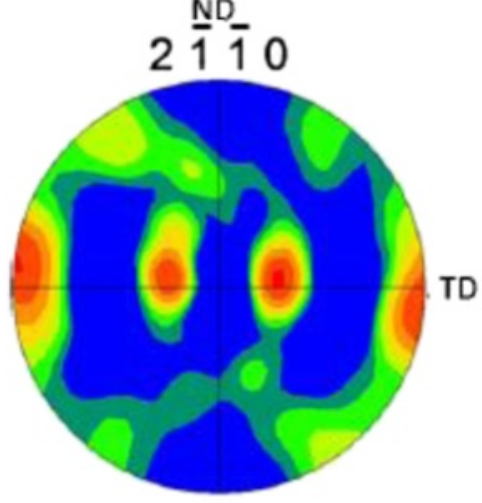

Nn



ND

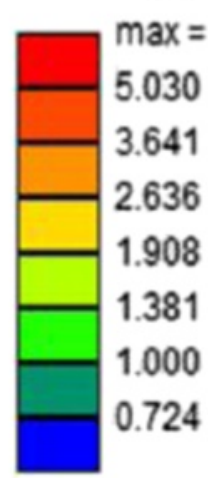

Fig. 2 Pole figure of unstrained specimen taken from the center of the sheet from the plane normal to the loading axis collected from a $160 \mu \mathrm{m} \times 60 \mu \mathrm{m}$ area. The cleanup routine removed points with $\mathrm{Cl}<0.1$. Maximum multiple of random (MRD) of 6.948 shows a rolling texture present

at approximately $520{ }^{\circ} \mathrm{C}$ [11]. The exact processing history of the tested sheet is not known with certainty; however, it is believed that the sheet was subjected to a duplex annealing process. The alloy was found to contain $94 \%$ primary alpha with the remainder made up by the beta phase, which corresponds with previously reported values [12]. The chemical makeup of the coupons tested can be seen in Table 1.

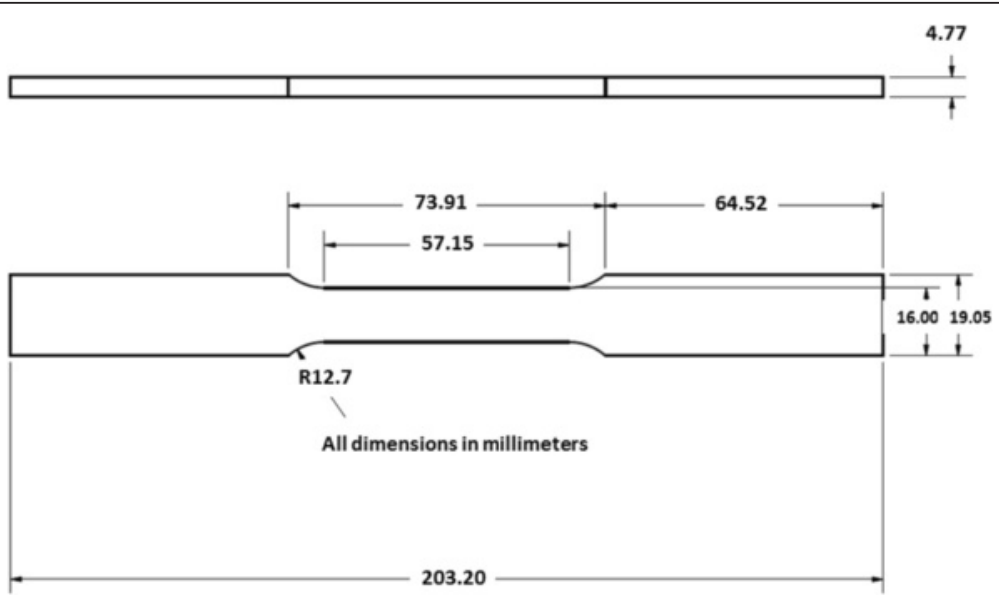

Fig. 3 ASTM E-8 specimen geometry for sheet tensile testing 


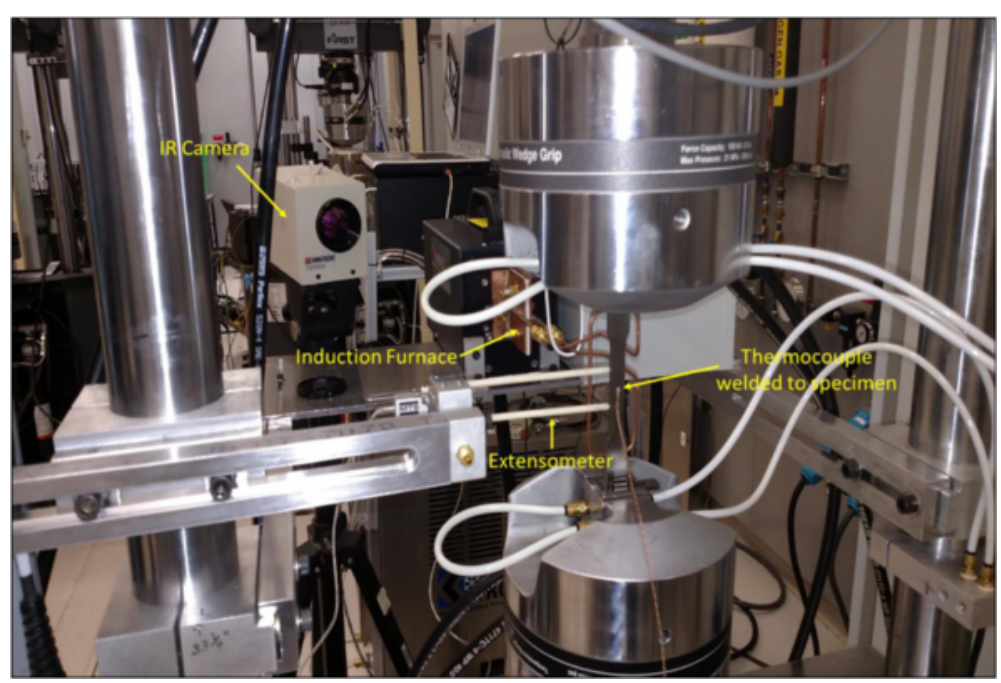

Fig. 4 Low-temperature tensile test setup showing extensometer, induction furnace, and temperature control. The induction heating coil is the single copper loop surrounding the vertically mounted tensile sample. The extensometer has ceramic arms between the gage and the sample attachment

Electron backscatter pattern imaging was performed on an untested sample using a $\mathrm{FEI}^{\mathrm{Tw}}$ XL-30. The resulting ND inverse pole figure map of the microstructure showing the grain morphology as well as the orientation of the grains can be seen in Fig. 1. The corresponding pole figure illustrating a rolling texture can be seen in Fig. 2. The raw *ang files [1] that Figs. 1 and 2 illustrate are available.

The sheet of Ti-6242S was machined to the ASTM E-8 [13] standard for flat tensile specimens. The specimens were machined using a milling machine, and one face was machined to maintain the $4.77-\mathrm{mm}$ thickness. No heat treatments were performed post machining. The specimen dimensions are shown in Fig. 3.

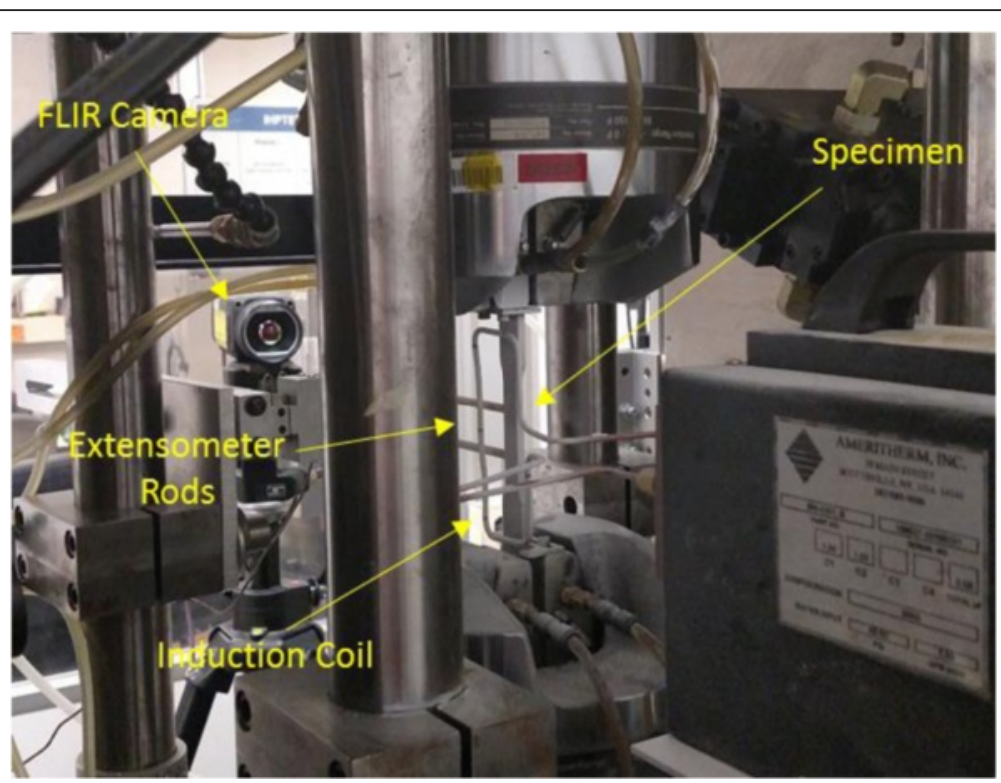

Fig. 5 High-temperature tensile test setup showing extensometer, induction coil, and specimen. Note that the orientation of the specimen has been rotated by $90^{\circ}$ in relation to the low-temperature setup 
Table 2 Test matrix illustrating conditions and number of repeats

\begin{tabular}{llll}
\hline Test condition \# & Temperature $\left({ }^{\circ} \mathrm{C}\right)$ & Strain rate $(1 / \mathrm{s})$ & Number of repeats \\
\hline 1 & 23 & $1 \times 10^{-4}$ & 5 \\
2 & 23 & $10^{-2}$ & 5 \\
3 & 100 & $8.33 \times 10^{-5}$ & 4 \\
4 & 100 & $10^{-2}$ & 3 \\
5 & 200 & $8.33 \times 10^{-5}$ & 3 \\
6 & 200 & $10^{-2}$ & 3 \\
7 & 316 & $8.33 \times 10^{-5}$ & 3 \\
8 & 316 & $10^{-2}$ & 3 \\
9 & 427 & $8.33 \times 10^{-5}$ & 3 \\
10 & 427 & $10^{-2}$ & 3 \\
11 & 538 & $8.33 \times 10^{-5}$ & 3 \\
12 & 538 & $10^{-2}$ & 3 \\
13 & 600 & $8.33 \times 10^{-5}$ & 3 \\
14 & 600 & $10^{-2}$ & 3 \\
15 & 650 & $8.33 \times 10^{-5}$ & 3 \\
16 & 650 & $10^{-2}$ & 3 \\
\hline
\end{tabular}

The specimens were cleaned using a degreasing method [14] that calls for repeated baking at $190{ }^{\circ} \mathrm{C}$ and cleaning with acetone and ethanol alcohol. This method was repeated three times on each specimen with the purpose of removing the oils from machining and production. The removal of the oils allows for cleaner and more reliable thermocouple welds, which are critical for testing that induces large strain $(\geq 10 \%)$ in the gage length.

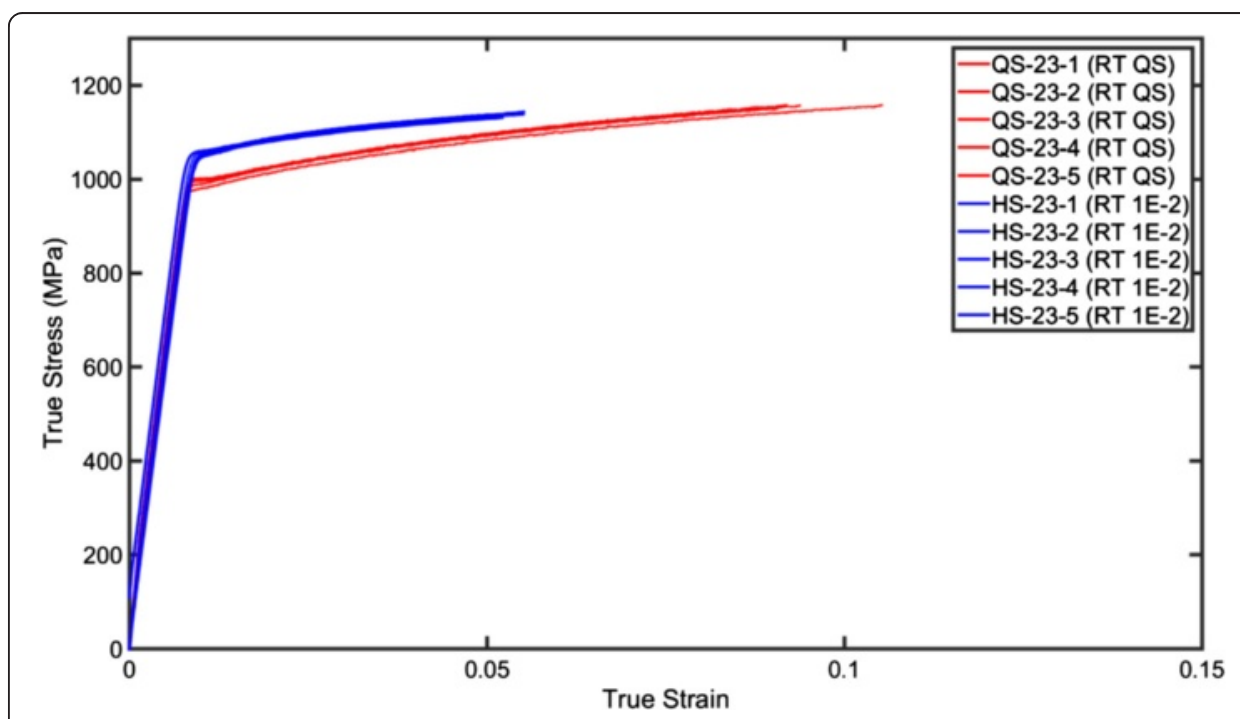

Fig. 6 True stress-true strain plot at $23^{\circ} \mathrm{C}$, showing minimal variance between the repeats, and a small, positive strain-rate sensitivity. Each test is labeled as strain rate (QS = quasi-static or $\mathrm{HS}=$ high speed)temperature-test number 
Table 3 Actual strain rates, ultimate stress, and elongation to failure of specimens tested at $23^{\circ} \mathrm{C}$

\begin{tabular}{lllll}
\hline Specimen \# & Temperature $\left({ }^{\circ} \mathrm{C}\right)$ & Actual rate $(1 / \mathrm{s})$ & Ultimate engineering stress $(\mathrm{MPa})$ & Elongation to failure (\%) \\
\hline QS-23-1 & 23 & $6.86 \mathrm{E}-05$ & 1057 & 12.5 \\
QS-23-2 & 23 & $6.97 \mathrm{E}-05$ & 1062 & 11.9 \\
QS-23-3 & 23 & $7.05 \mathrm{E}-05$ & 1058 & 15.8 \\
QS-23-4 & 23 & $7.03 \mathrm{E}-05$ & 1057 & 14.7 \\
QS-23-5 & 23 & $7.24 \mathrm{E}-05$ & 1049 & 18.3 \\
HS-23-1 & 23 & $7.60 \mathrm{E}-03$ & 1078 & 13.7 \\
HS-23-2 & 23 & $7.30 \mathrm{E}-03$ & 1074 & $8.7^{\mathrm{a}}$ \\
HS-23-3 & 23 & $7.50 \mathrm{E}-03$ & 1079 & 14.1 \\
HS-23-4 & 23 & $7.30 \mathrm{E}-03$ & 1079 & $9.2^{\mathrm{a}}$ \\
HS-23-5 & 23 & $7.60 \mathrm{E}-03$ & 1083 & 10.8 \\
\hline
\end{tabular}

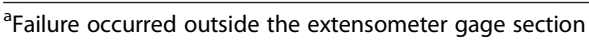

\section{Heating method}

\section{Low-temperature testing}

The specimens tested at $316{ }^{\circ} \mathrm{C}$ and below were heated using a 6-kW inductive furnace with a flat, single-turn, pancake-style coil placed approximately $3 \mathrm{~mm}$ from the face of the specimen. The coil along with the test setup can be seen in Fig. 4. The temperature profile at each test condition was controlled using a single thermocouple spot-welded to the center of the gage section on the face opposite the coil and connected to a Eurotherm $^{\text {mi }}$ stand-alone controller. While a single thermocouple allowed for ample control, each condition's thermal profile was checked using a specimen with three thermocouples spanning the gage section along with an optical pyrometer and a Mikron $^{\text {tw }}$ TS7302 infra-red (IR) camera. The vertical placement of the specimen relative to the coil was adjusted until the maximum variation in temperature was within $5{ }^{\circ} \mathrm{C}$. Before each test was performed, the specimen was held at temperature for 10 min prior to using the IR camera to ensure that the thermal profile was spatially

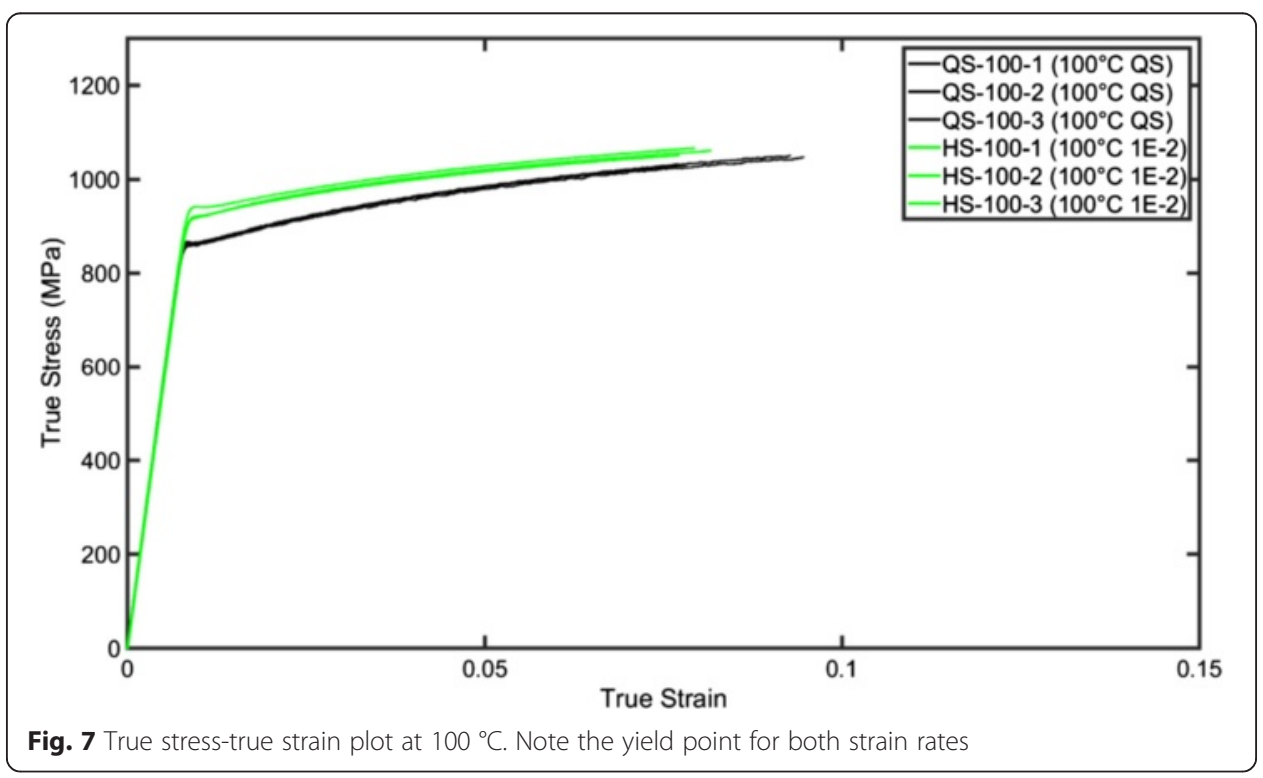


Table 4 Actual strain rates, ultimate stress, and elongation to failure of specimens tested at $100{ }^{\circ} \mathrm{C}$

\begin{tabular}{lllll}
\hline Specimen \# & Temperature $\left({ }^{\circ} \mathrm{C}\right)$ & Actual rate $(1 / \mathrm{s})$ & Ultimate engineering stress (MPa) & Elongation to failure (\%) \\
\hline QS-100-1 & 100 & $6.59 \mathrm{E}-05$ & 958 & $8.11^{\mathrm{a}}$ \\
QS-100-2 & 100 & $6.81 \mathrm{E}-05$ & 962 & 11.6 \\
QS-100-3 & 100 & $7.00 \mathrm{E}-05$ & 958 & 13.9 \\
HS-100-1 & 100 & $8.50 \mathrm{E}-03$ & 981 & 15.9 \\
HS-100-2 & 100 & $8.20 \mathrm{E}-03$ & 988 & 14.3 \\
HS-100-3 & 100 & $8.10 \mathrm{E}-03$ & 977 & 12.2 \\
\hline
\end{tabular}

${ }^{\mathrm{a}}$ Denotes failure occurred outside the extensometer gage section

uniform. In order to use the IR camera, one face of the specimen was painted black using high-temperature paint in order to maintain a constant emissivity value. This value was measured using a calibrated emissivity meter before and after heating. This step was critical to ensure the same geometry and thermal conditions were applied to each and every specimen.

\section{High-temperature testing}

The specimens tested at $427^{\circ} \mathrm{C}$ and above were heated using the same 6-kW inductive furnace and the flat, single-turn, pancake-style coil. Instead of using an IR camera to ensure an acceptable temperature gradient, a forward-looking infra-red (FLIR) FLIR ${ }^{\mathrm{mx}}$ A655SC camera was employed to monitor the full-field thermal conditions. The hightemperature test setup can be seen in Fig. 5. To maintain a constant emissivity of approximately 0.95 , the aerosol developer Spotcheck SKD-S2 was applied to the specimen prior to heating.

\section{Test setup and data collection}

The tests performed at $316{ }^{\circ} \mathrm{C}$ and below were conducted on a $200-\mathrm{kN}$ MTS ${ }^{\mathrm{ma}}$ load frame equipped with a $100-\mathrm{kN}$ actuator and load cell. In order to measure strain,

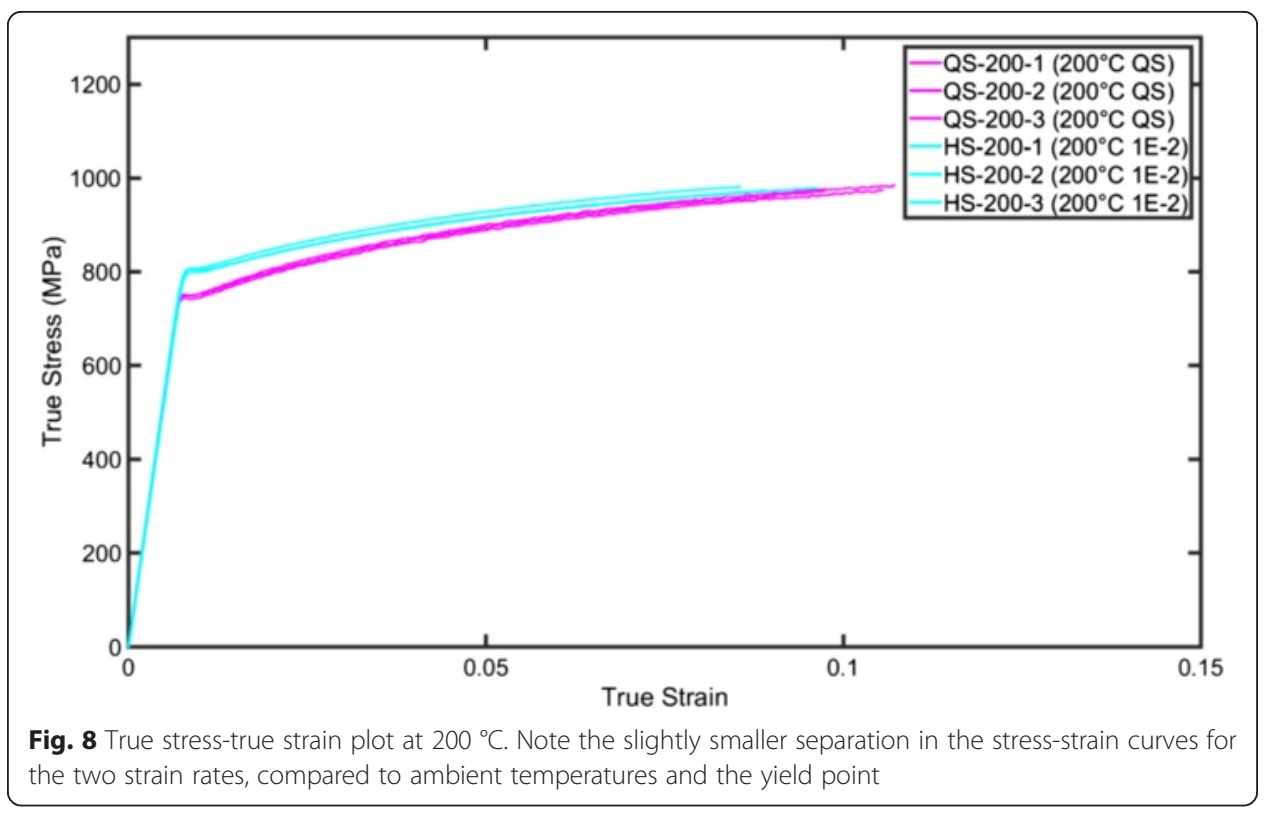


Table 5 Actual strain rates, ultimate stress, and elongation to failure of specimens tested at $200{ }^{\circ} \mathrm{C}$

\begin{tabular}{lllll}
\hline Specimen \# & Temperature $\left({ }^{\circ} \mathrm{C}\right)$ & Actual rate $(1 / \mathrm{s})$ & Ultimate engineering stress $(\mathrm{MPa})$ & Elongation to failure (\%) \\
\hline QS-200-1 & 200 & $6.98 \mathrm{E}-05$ & 890 & $>30$ \\
QS-200-2 & 200 & $7.22 \mathrm{E}-05$ & 883 & $>30$ \\
QS-200-3 & 200 & $7.19 \mathrm{E}-05$ & 887 & $>30$ \\
HS-200-1 & 200 & $8.40 \mathrm{E}-03$ & 894 & 12 \\
HS-200-2 & 200 & $8.70 \mathrm{E}-03$ & 893 & 17 \\
HS-200-3 & 200 & $8.40 \mathrm{E}-03$ & 904 & 16.9 \\
\hline
\end{tabular}

an MTS $^{\mathrm{TM}}$ 632.50E-02 high-temperature extensometer was used that was calibrated using standard methods to handle $0-30 \%$ strain with a 25.4-mm gage section. The wedges used to grip the specimen were water-cooled to protect the hydraulic oil within the grips. The tests were performed using MTS's Basic TestWare ${ }^{\mathrm{rm}}$ software package and utilized displacement rate control to apply the required strain rates. For each specimen, load, displacement, strain, and temperature data were collected at either 10 or $1000 \mathrm{~Hz}$, corresponding to either quasi-static or $10^{-2} / \mathrm{s}$ strain rates, respectively.

Testing performed at $427^{\circ} \mathrm{C}$ and above was conducted on a custom 62-kN test frame designed for biaxial testing. The load cell was calibrated up to $44.4 \mathrm{kN}$, and the actuator is capable of applying $63 \mathrm{kN}$. The same MTS high-temperature extensometer was utilized along with the same water-cooled wedges. The tests on this frame were conducted using MTS's Multi-Purpose TestWare ${ }^{\mathrm{Tm}}$ software suite and used displacement rate control to enforce the desired strain rates.

\section{Test conditions}

The purpose of this experimental campaign was to characterize Ti-6242S tensile response under various thermal and loading rate conditions. The full test matrix is provided in Table 2. At each condition, repeats were performed.

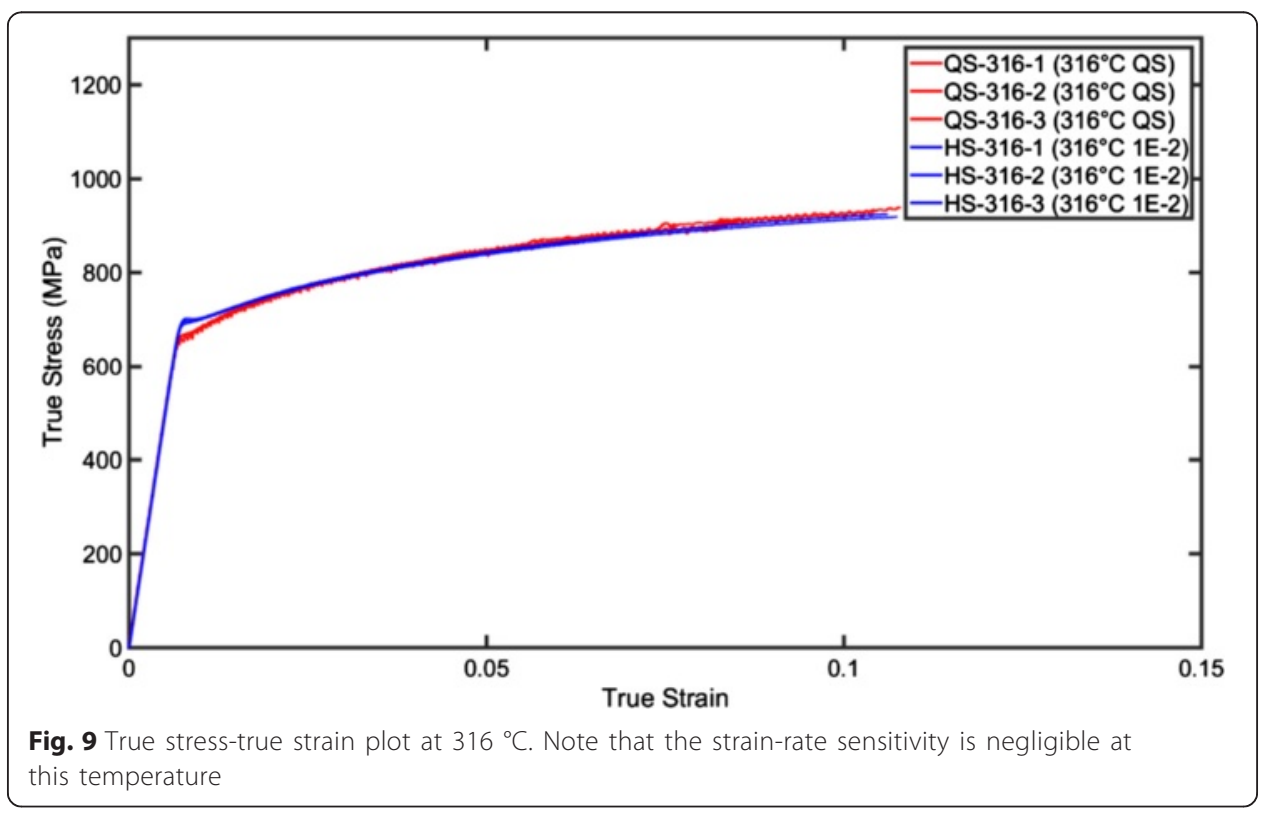


Table 6 Actual strain rates, ultimate stress, and elongation to failure of specimens tested at $316^{\circ} \mathrm{C}$

\begin{tabular}{lllll}
\hline Specimen \# & Temperature $\left({ }^{\circ} \mathrm{C}\right)$ & Actual rate $(1 / \mathrm{s})$ & Ultimate engineering stress $(\mathrm{MPa})$ & Elongation to failure (\%) \\
\hline QS-316-1 & 316 & $7.35 \mathrm{E}-05$ & 846 & 11.9 \\
QS-316-2 & 316 & $7.53 \mathrm{E}-05$ & 848 & 13.6 \\
QS-316-3 & 316 & $6.92 \mathrm{E}-05$ & 843 & 10.8 \\
HS-316-1 & 316 & $9.20 \mathrm{E}-03$ & 830 & 16.8 \\
HS-316-2 & 316 & $9.30 \mathrm{E}-03$ & 836 & 15.7 \\
HS-316-3 & 316 & $7.60 \mathrm{E}-03$ & 823 & 18 \\
\hline
\end{tabular}

\section{Experimental results}

The results from the experimental investigation are organized into sections by the test temperature applied to the specimen. Thus, what follows are sections ranging from $23{ }^{\circ} \mathrm{C}$ up to $650{ }^{\circ} \mathrm{C}$, each with one figure that shows the true stress-true strain response of each strain rate at the specified temperature. Additionally, each section contains a table that details the actual strain rate applied to each specimen, the ultimate stress, and the elongation to failure. While each plot is cut off at the ultimate tensile load, the raw data file contains the full strain and load history. The raw experimental data files and supporting information are available at [1].

$23{ }^{\circ} \mathrm{C}$

The resulting stress-strain curves from the ten tests at $23{ }^{\circ} \mathrm{C}$ can be seen in Fig. 6 . The data shows an increase in the yield strength as well as overall strength at the elevated strain rate $\left(10^{-2} / \mathrm{s}\right)$ when compared to the quasi-static rate. The actual test strain rate, the ultimate stress, and the elongation to failure are given in Table 3.

$100^{\circ} \mathrm{C}$

The specimens were heated to a temperature of $100{ }^{\circ} \mathrm{C}$ with a variation of no more than $2{ }^{\circ} \mathrm{C}$ along the gage section. The stress-strain response at $100{ }^{\circ} \mathrm{C}$ is

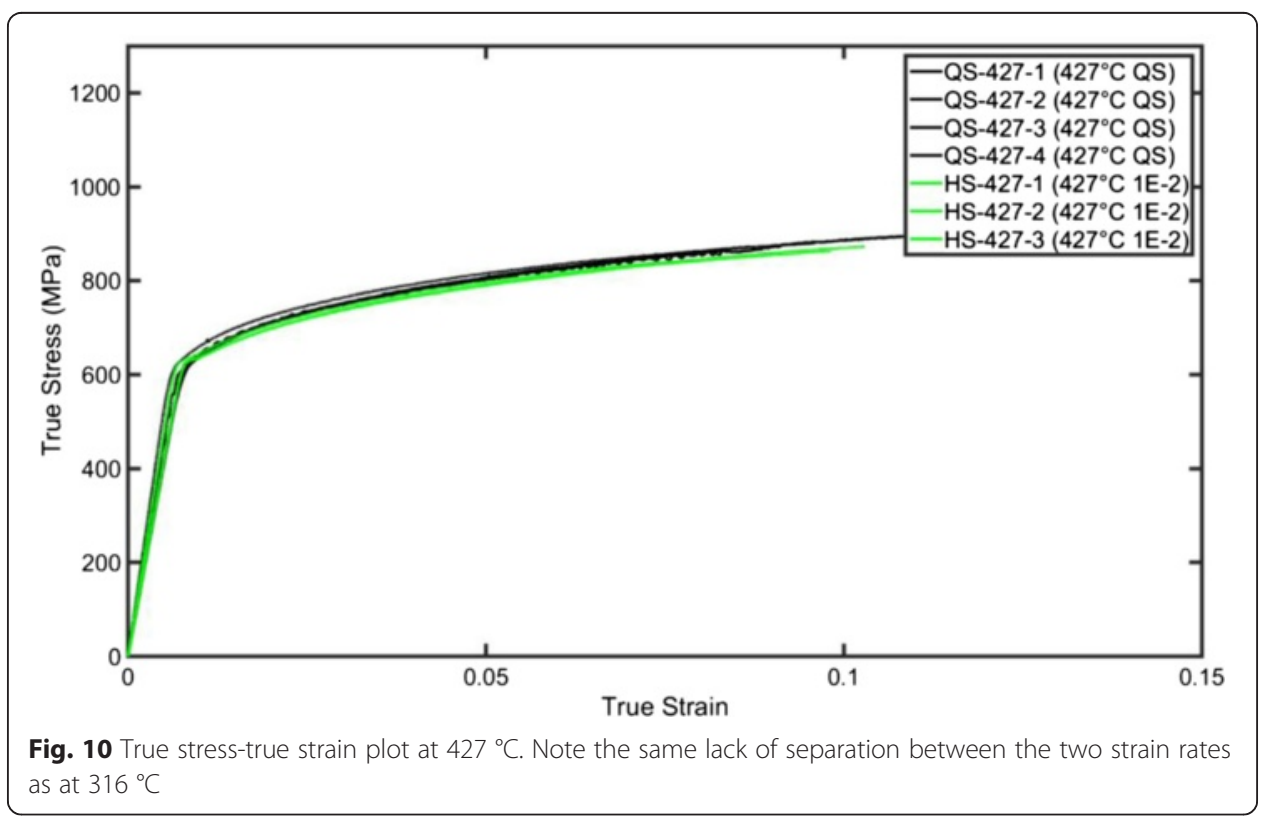


Table 7 Actual strain rates, ultimate stress, and elongation to failure of specimens tested at $427^{\circ} \mathrm{C}$

\begin{tabular}{lllll}
\hline Specimen \# & Temperature $\left({ }^{\circ} \mathrm{C}\right)$ & Actual rate $(1 / \mathrm{s})$ & Ultimate engineering stress $(\mathrm{MPa})$ & Elongation to failure (\%) \\
\hline QS-427-1 & 427 & $6.24 \mathrm{E}-05$ & 798 & 9.2 \\
QS-427-2 & 427 & $8.07 \mathrm{E}-05$ & 808 & 13.1 \\
QS-427-3 & 427 & $7.50 \mathrm{E}-05$ & 808 & 12 \\
QS-427-4 & 427 & $6.14 \mathrm{E}-05$ & 803 & 10.7 \\
HS-427-1 & 427 & $1.00 \mathrm{E}-02$ & 786 & 10.8 \\
HS-427-2 & 427 & $1.10 \mathrm{E}-02$ & 791 & 17.8 \\
HS-427-3 & 427 & $8.30 \mathrm{E}-03$ & 781 & 11.7 \\
\hline
\end{tabular}

shown in Fig. 7, and the actual test strain rate, the ultimate stress, and the elongation to failure are shown in Table 4. Again, the data show an increase in yield strength with the increasing strain rate as well as work hardening over the entire strain path.

$200{ }^{\circ} \mathrm{C}$

The temperature was held to within $3{ }^{\circ} \mathrm{C}$ of $200{ }^{\circ} \mathrm{C}$. The experimentally obtained stress-strain curves can be seen in Fig. 8, and the actual test strain rate, the ultimate stress, and the elongation to failure can be found in Table 5. Yield strength again increases with the elevated strain rate.

$316^{\circ} \mathrm{C}$

The specimens were heated using the standard procedure and displayed a deviation in temperature of $3{ }^{\circ} \mathrm{C}$ at $316{ }^{\circ} \mathrm{C}$. The results of the testing are shown in Fig. 9, and the actual test strain rate, the ultimate stress, and the elongation to failure can be found in Table 6 . The yield strength of the higher strain rate remains above the quasi-static rate, but the ultimate tensile stress decreases with the $10^{-2} / \mathrm{s}$ strain rate.



Fig. 11 True stress-true strain plot at $538^{\circ} \mathrm{C}$. Note the separation between the two strain rates, which shows that a positive strain-rate sensitivity has reappeared at this temperature 
Table 8 Actual strain rates, ultimate stress, and elongation to failure of specimens tested at $538^{\circ} \mathrm{C}$

\begin{tabular}{lllll}
\hline Specimen \# & Temperature $\left({ }^{\circ} \mathrm{C}\right)$ & Actual rate $(1 / \mathrm{s})$ & Ultimate engineering stress $(\mathrm{MPa})$ & Elongation to failure $(\%)$ \\
\hline QS-538-1 & 538 & $4.82 \mathrm{E}-05$ & 333 & $7.8^{\mathrm{a}}$ \\
QS-538-2 & 538 & $4.76 \mathrm{E}-05$ & 337 & $7.0^{\mathrm{a}}$ \\
QS-538-3 & 538 & $6.27 \mathrm{E}-05$ & 339 & 16.8 \\
HS-538-1 & 538 & $7.60 \mathrm{E}-03$ & 718 & $9.0^{\mathrm{a}}$ \\
HS-538-2 & 538 & $7.70 \mathrm{E}-03$ & 694 & 13.4 \\
HS-538-3 & 538 & $7.20 \mathrm{E}-03$ & 719 & $8.2^{\mathrm{a}}$ \\
\hline
\end{tabular}

${ }^{\mathrm{a}}$ Denotes failure occurred outside the extensometer gage section

$427^{\circ} \mathrm{C}$

The specimens tested at $427{ }^{\circ} \mathrm{C}$ were tested across the two test frames. The temperature difference measured across the gage section using a FLIR camera was $3{ }^{\circ} \mathrm{C}$. Figure 10 shows that there is almost no difference between the quasi-static and higher strain rates, which implies negligible strain-rate sensitivity at this temperature. The actual test strain rate, the ultimate stress, and the elongation to failure can be seen in Table 7.

$538{ }^{\circ} \mathrm{C}$

At $538{ }^{\circ} \mathrm{C}$, the thermal gradient measured across the gage section was $3{ }^{\circ} \mathrm{C}$. The constitutive response is shown in Fig. 11. The response shows an increase in yield strength as well as ultimate strength at the $10^{-2} / \mathrm{s}$ strain rate. The actual test strain rate, the ultimate stress, and the elongation to failure at $538{ }^{\circ} \mathrm{C}$ can be seen in Table 8 .

$600^{\circ} \mathrm{C}$

The maximum temperature deviation along the gage section was $3{ }^{\circ} \mathrm{C}$. However, because the amount of total elongation has increased, the thermal gradient in the gage

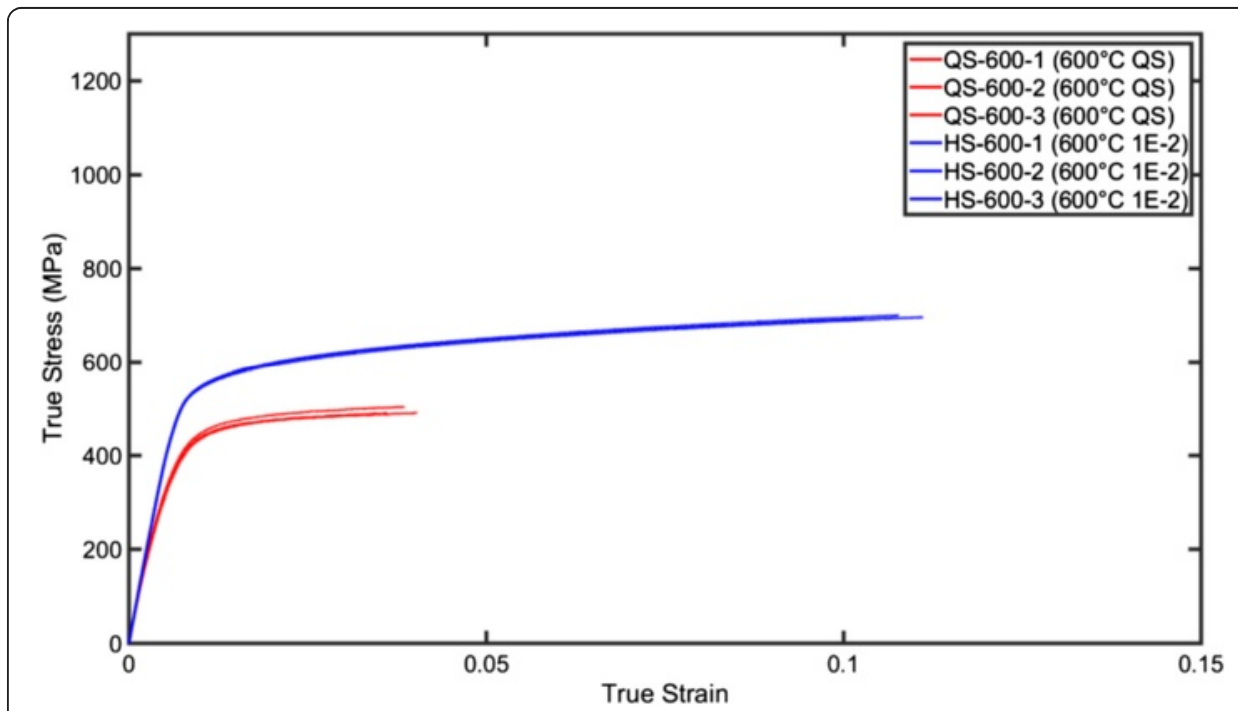

Fig. 12 True strain-true stress plot at $600{ }^{\circ} \mathrm{C}$. Note the larger separation between the two strain rates than for lower test temperatures 
Table 9 Actual strain rates, ultimate stress, and elongation to failure of specimens tested at $600{ }^{\circ} \mathrm{C}$

\begin{tabular}{lllll}
\hline Specimen \# & Temperature $\left({ }^{\circ} \mathrm{C}\right)$ & Actual rate $(1 / \mathrm{s})$ & Ultimate engineering stress $(\mathrm{MPa})$ & Elongation to failure (\%) \\
\hline QS-600-1 & 600 & $6.19 \mathrm{E}-05$ & 333 & $>30$ \\
QS-600-2 & 600 & $6.16 \mathrm{E}-05$ & 337 & 24 \\
QS-600-3 & 600 & $6.47 \mathrm{E}-05$ & 339 & $>30$ \\
HS-600-1 & 600 & $9.90 \mathrm{E}-03$ & 626 & 27.8 \\
HS-600-2 & 600 & $9.90 \mathrm{E}-03$ & 628 & 28.5 \\
HS-600-3 & 600 & $1.00 \mathrm{E}-02$ & 631 & 27.4 \\
\hline
\end{tabular}

section changed during the test as the gage section increased approximately $50 \%$ in length during the quasi-static tests. This has the largest effect on the tail end of the data and little to no effect on the yield and ultimate strengths. The resulting true strain-true stress plot can be seen in Fig. 12 and the actual test strain rate, the ultimate stress, and the elongation to failure for each test can be seen in Table 9.

$650{ }^{\circ} \mathrm{C}$

At the test temperature of $650{ }^{\circ} \mathrm{C}$, the specimens had a thermal gradient with a maximum deviation of $4{ }^{\circ} \mathrm{C}$ prior to testing. As seen at $600{ }^{\circ} \mathrm{C}$, the amount of elongation seen caused the gradient to change during the test but only after large (>30\%) engineering strains. At this condition, the extensometer had to be removed at its maximum displacement of $30 \%$ to prevent damage to the extensometer but the test was allowed to run until failure. Thus, the data files contain displacements and loads up to failure, but the strain measurements stop at approximately $31 \%$ strain. The strain-rate sensitivity increased again at this temperature with the $10^{-2} / \mathrm{s}$ rate's yield and ultimate strengths being much larger than the quasi-static rate. The response is shown in Fig. 13 and the actual test strain rate, the ultimate stress, and the elongation to failure in Table 10.

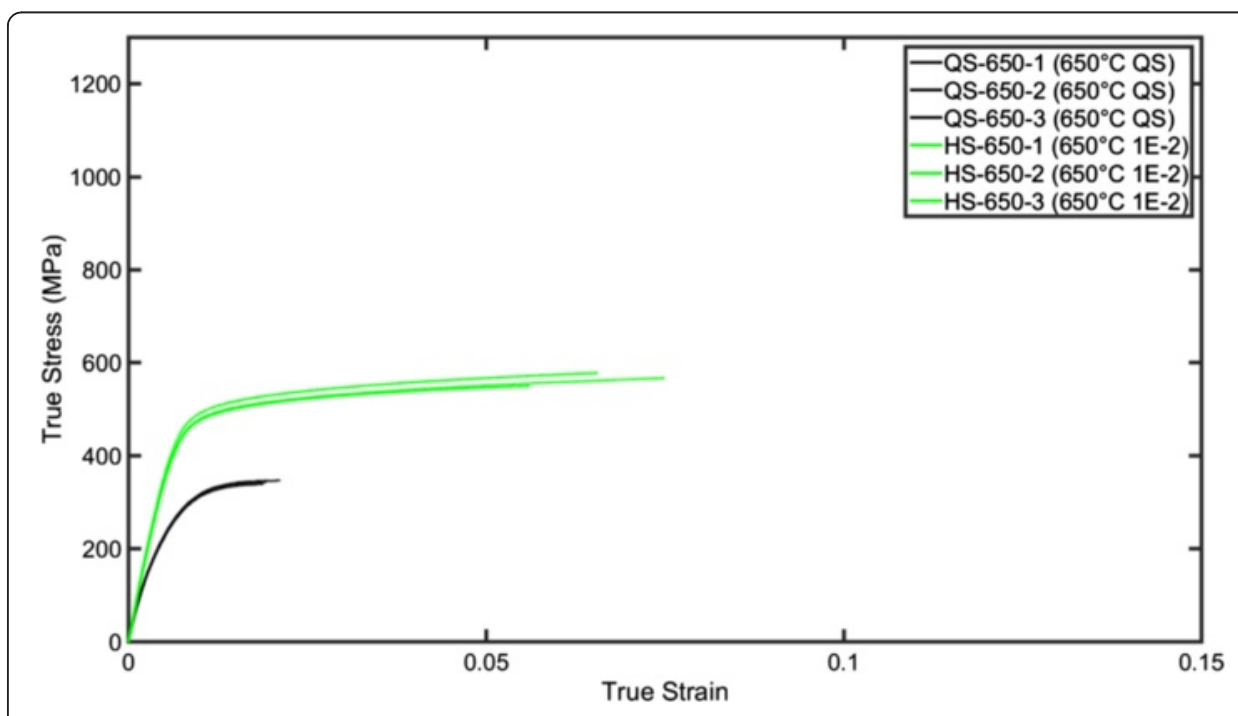

Fig. 13 True strain-true stress plot at $650^{\circ} \mathrm{C}$. Note the substantial strain-rate sensitivity and the rapid loss of work hardening, especially for the lower strain rate 
Table 10 Actual strain rates, ultimate stress, and elongation to failure of specimens tested at $650{ }^{\circ} \mathrm{C}$

\begin{tabular}{lllll}
\hline Specimen \# & Temperature $\left({ }^{\circ} \mathrm{C}\right)$ & Actual rate $(1 / \mathrm{s})$ & Ultimate engineering stress $(\mathrm{MPa})$ & Elongation to failure (\%) \\
\hline QS-650-1 & 650 & $5.64 \mathrm{E}-05$ & 333 & $>30$ \\
QS-650-2 & 650 & $5.92 \mathrm{E}-05$ & 337 & $>30$ \\
QS-650-3 & 650 & $6.14 \mathrm{E}-05$ & 339 & $>30$ \\
HS-650-1 & 650 & $9.50 \mathrm{E}-03$ & 542 & $>30$ \\
HS-650-2 & 650 & $8.60 \mathrm{E}-03$ & 528 & $>30$ \\
HS-650-3 & 650 & $7.50 \mathrm{E}-03$ & 521 & $9^{\mathrm{a}}$ \\
\hline
\end{tabular}

${ }^{\mathrm{a}}$ Denotes failure occurred outside the extensometer gage section

\section{Potential applications}

The material characterization and experimental results detailed here are intended to supplement and support the available tensile stress-strain data available in literature. To the authors' knowledge, this is the first data for temperatures between room temperature and $316^{\circ} \mathrm{C}$ as well as data above $538^{\circ} \mathrm{C}$ in tensile loading. The use of two different strain rates also provides important data on strain-rate sensitivity for yield and work hardening. Thus, this dataset can be used to build, develop, and test constitutive models across length scales encompassing a wide range of thermal environments as well as the two loading rates investigated. The data presented provide yield strength, plasticity behavior, ultimate strength, and failure information with repeated tests performed under as similar conditions as possible. Possible applications of this data are:

1. Developing crystal plasticity models from the measured texture and grain size information contained within the *.ang files.

2. Analysis of yield strength as the temperature and strain rate are varied across the design space.

3. Constitutive properties can be used to develop and train models as well as test existing models in areas where experimental data was not readily available.

4. The multiple repeats of each test condition were performed back-to-back, so the variability due to the testing conditions should be minimized. Thus, a study on the variability of material properties could be performed as well as comparison to other datasets that have been published throughout the decades.

\section{Availability and requirements of software used}

The experimental tensile data was collected using the MTS software packages Basic Testware $\left(23{ }^{\circ} \mathrm{C}-316{ }^{\circ} \mathrm{C}\right)$ and Multipurpose Testware $\left(427{ }^{\circ} \mathrm{C}-650{ }^{\circ} \mathrm{C}\right)$. The provided data file are in ASCII text format and do not require these software packages for use. The EDAX OIM data collection software package was used to collect the microstructural texture files and the EDAX OIM analysis software package was used to generate the pole figure and inverse pole figure map. The provided microstructural texture files are in text format and do not require the use of the either software package.

\section{Availability of Supporting Data}

The datasets described in this article are available in the NIST repository [1]. 


\section{Acknowledgements}

The authors would like to acknowledge the support of the FIRST Laboratory at the Air Force Research Laboratory (AFRL) for their assistance in developing the test setup and protocol. Specifically, the support of Jason Portemont and Brian Smyers is gratefully acknowledged. Also, the assistance and hospitality of the Turbine Engine Fatigue Facility (TEFF) at the AFRL is gratefully recognized for providing the biaxial frame to allow the high-temperature testing to continue. Specifically, the support of Casey Holycross, Bryan Langley, and Tommy George is gratefully acknowledged.

\section{Authors' contributions}

BTG designed and conducted the experiments detailed in the paper and provided engineering and scientific contributions to the work. RSK assisted in conducting the experiments, provided critical design and manufacturing insight pertaining to the induction coil design, and assisted in the general troubleshooting. ADR provided oversight and guidance on the development and analysis of the experimental program. All authors have approved the manuscript.

\section{Competing interests}

The authors declare that they have no competing interests.

Received: 23 April 2016 Accepted: 15 August 2016

Published online: 05 September 2016

\section{References}

1. Gockel BT, Kolesar RS, Rollett AD (2016) Experimental study of Ti-6Al-2Sn-4Zr-2Mo-0.1Si under various thermal and tensile loading rate conditions., http://hdl.handle.net/11256/668

2. Follansbee PS, Kocks UF (1988) A constitutive description of the deformation of copper based on the use of the mechanical threshold stress as an internal state variable. Acta Metall 36:81-93

3. Semiatin SL, Thomas JF, Dadras P (1983) Processing microstructure relationships for Ti-6Al-2Sn-4Zr-2Mo-0.1Si. Metallurgical Transactions A 14A:2363-2374

4. ASM International (2002) Atlas of stress-strain curves, 2nd edn

5. Zuchowski B (2012) Predictive capability for hypersonic structural response and life prediction: phase II-detailed design of a hypersonic cruise vehicle hot-structure, AFRL-RQ-WP-TR-2012-0280. U.S. Air Force, WPAFB

6. Department of defense handbook. Metallic materials and elements for aerospace vehicle structures, MIL-HDBK-5J ed., 2003

7. Zuchowski B (2010) Predictive capability for hypersonic structural response and life prediction, phase I-identification of knowledge gaps, AFRL-RB-WP-TR-2010-3069. U.S. Air Force, WPAFB

8. Lütjering G, Williams JC (2007) Titanium., Springer

9. Donachie MJ Jr (2000) Titanium—a technical guide, 2nd edn., ASM International, Materials Park, OH

10. Chandler H (1996) Heat treater's guide: practices and procedures for nonferrous alloys., ASM International, Materials Park, $\mathrm{OH}$

11. Hayes RW, Viswanthan GB, Mills MJ (2002) Creep behavior of Ti-6Al-2Sn-4Zr-2Mo: I. The effect of nickel on creep deformation and microstructure. Acta Mater 50(20):4953-4963

12. Pilchak AL, Szczepanski CJ, Shaffer JA, Salem AA, Semiatin SL (2013) Characterization of microstructure, texture, and microtexture in near-alpha titanium mill products, Metallurgical and Materials Transactions A

13. ASTM E8/E8M-15a (2015) Standard test methods for tension testing of metallic materials. ASTM International, West Conshohocken, PA

14. Surface Preparation for Strain Gage Bonding, Instruction Bulletin B-129-8 (2014). Micro Measurements, Raleigh, NC

\section{Submit your manuscript to a SpringerOpen ${ }^{\circ}$ journal and benefit from:}

- Convenient online submission

- Rigorous peer review

- Immediate publication on acceptance

- Open access: articles freely available online

- High visibility within the field

- Retaining the copyright to your article 